\title{
Physiological Research on Winter-hardiness: Deacclimation Resistance, Reacclimation Ability, Photoprotection Strategies, and a Cold Acclimation Protocol Design
}

\author{
Rajeev Arora ${ }^{1}$ \\ Department of Horticulture, 139 Horticulture Hall, Iowa State University, Ames, IA 50011-1100 \\ Lisa J. Rowland \\ U.S. Department of Agriculture, Agricultural Research Service, Henry A. Wallace Agricultural \\ Research Center, Genetic Improvement of Fruits and Vegetables Laboratory, Building 010A, \\ BARC-West, Beltsville, MD 20705
}

Additional index words. freezing tolerance, climate change, ELIPS, rhododendron, blueberry, endodormancy

\begin{abstract}
Freezing is a major environmental stress during an annual cycle of overwintering, temperate-zone perennials. The timing and extent of seasonal cold acclimation (development of freezing tolerance in the fall) and deacclimation (loss of acquired freezing tolerance in response to warm temperatures) are of critical importance for winter survival, particularly in view of the climate change, i.e., unpredictable extreme weather occurrences. For example, plants may acclimate inadequately if exposed to a milder fall climate and may be damaged by sudden frosts. Alternatively, they may deacclimate prematurely as a result of unseasonable, midwinter warm spells and be injured by the cold that follows. Efficient cold acclimation ability, high deacclimation resistance, and efficient reacclimation capacity are, therefore, important components of winter survival in overwintering perennials. These components should be evaluated separately for a successful breeding program focused on improving winter-hardiness. Another layer of complexity that should be carefully considered is that endodormant status (shallow versus deep) of the reproductive/vegetative apices can significantly impact these components of winter-hardiness. Winter survival, especially by woody evergreens, requires tolerance of light stress, which can result in photo-oxidative damage at cold temperatures when biochemistry of photosynthesis is somewhat compromised but light harvesting is unaffected. Accumulation of Elips (early light-induced proteins) in overwintering evergreens during winter represents a relatively novel strategy to cope with such light stress, and investigations on the precise cellular mechanism and genetic control of this strategy deserve research in the future. Investigations into the mechanisms for cold acclimation use laboratory-based, artificial acclimation protocols that often do not closely approximate conditions that plants are typically exposed to in nature. To draw meaningful conclusions about the biology of cold acclimation and ultimately improve freeze resistance under field conditions, one should also include in cold acclimation regimens parameters such as exposure to subfreezing temperatures and realistic diurnal temperature fluctuations and light levels to simulate natural conditions. One of the main objectives of this article is to highlight two areas of research that we believe are important in the context of plant cold-hardiness but, so far, have not received much attention. These are: 1) to understand the biology of deacclimation resistance and reacclimation capacity, two important components of freeze-stress resistance (winter-hardiness) in woody perennials; and 2) to investigate the cellular basis for various strategies used by broad-leaved evergreens for photoprotection during winter. Our emphasis, in this context, is on a family of proteins, called Elips. The second objective of this article is to draw attention of the cold-hardiness research community to the importance of using realistic cold acclimation protocols in controlled environments that will approximate natural/field conditions to be better able to draw meaningful conclusions about the biology of cold acclimation and ultimately improve freeze resistance. Results from our work with Rhododendron (deciduous azaleas and broad-leaved evergreens), blueberry, and that of other researchers are discussed to support these objectives.
\end{abstract}

\section{COLD ACCLIMATION}

Freezing is a major environmental stress that can inflict injury to plant tissues. Plants, being poikilothermal, cannot escape damaging effects of extracellular ice and resultant cellular dehydration. Subfreezing temperatures, therefore, limit the productivity and geographical distribution of many wild and crop species. Considerable effort has been invested in understanding the cellular phys-

Received for publication 18 Feb. 2011. Accepted for publication 5 May 2011.

This paper was part of the colloquium "Improvement of Horticultural Crops for Abiotic Stress Tolerance" held 5 Aug. 2010 at the ASHS Conference, Palm Desert, CA, sponsored by the Vegetable Breeding (VGBR) Working Group, and co-sponsored by the Environmental Stress Physiology (STRS) Working Group.

${ }^{1}$ To whom reprint requests should be addressed; e-mail rarora@iastate.edu. iology, genetics, and molecular biology of plants' response to subfreezing temperatures (Bertrand and Castonguay, 2003; Gusta et al., 2009; Guy, 1990, 2003; Moffatt et al., 2006; Pearce and Fuller, 2001; Smallwood and Bowles, 2002; Wisniewski et al., 2003; Xin and Browse, 2000). Review of this literature indicates that understanding the cellular basis of cold acclimation (CA) or cold hardening has been one of the major approaches in the past few decades to study plants' response to subfreezing temperatures.

$\mathrm{CA}$ is the genetic ability of many species such as temperate-zone woody perennials to increase their freezing tolerance when nonacclimated (NA) tissues are exposed to inductive cues such as short days and/or low temperatures (as in the fall). It is one of the most-studied and best-characterized responses using both model systems and economically important species. Classic genetic studies have demonstrated that $\mathrm{CA}$ is a multigenic trait (Arora et al., 2000; Pan et al., 1994; Stone et al., 1993; Sutka, 1981). In recent years, systems biology research (using comparative transcriptomics, proteomics, and metabolomics with NA and CA tissues) coupled with mutational analysis of freezing tolerance (using mutants of model plants that are either "constitutively" or transgenically freeze-tolerant or lack CA ability) have significantly advanced our understanding of the signaling pathways and complex networks of molecular changes important for CA process (Browse and Lange, 2004; Hannah et al., 2005; Kaplan et al., 2006; Renaut et al., 2006; Van Buskirk and Thomashow, 2006; Warren, 1998).

\section{WINTER-HARDINESS AND CLIMATE CHANGE: IMPORTANCE OF \\ DEACCLIMATION RESISTANCE AND REACCLIMATION ABILITY}

For winter survival, woody perennials not only must acclimate to cold, but also must resist premature deacclimation as a result of 
unseasonable, midwinter warm spells. Deacclimation (DA) refers to reduction/loss of freezing tolerance originally attained through $\mathrm{CA}$ and, in nature, happens typically in early spring with the rise of temperatures. The topical interest in climate change particularly emphasizes the scenario of "premature or untimely DA" and resultant freeze damage. Temperate winters are becoming progressively milder as a result of climate warming, and temperature patterns are becoming increasingly irregular with risk of unseasonable warm spells (Arctic Climate Impact Assessment, 2005; Intergovernmental Panel on Climate Change, 2007), which can transiently deharden the plant tissues rendering them vulnerable to the risk of subsequent freezing injury (Kalberer et al., 2006). The historic 2007 Eastern US Spring Freeze, one of the most devastating in recent memory, exemplifies this phenomenon ( $\mathrm{Gu}$ et al., 2008). Depending on the depth of DA, it may be either irreversible or reversed by subsequent exposure to low temperatures that may cause re-acclimation (RA), i.e., the restoration of, at least, a portion of the lost tolerance. Thus, in addition to the existence of sufficient and efficient CA ability, high DA resistance and RA capacity are also important components of winter survival of plants (Kalberer et al., 2006). Despite its critical importance to winterhardiness, however, research on DA and RA has not received due attention.

\section{LIGHT STRESS IN OVERWINTERING EVERGREENS}

Another aspect of winter-hardiness that has not been well investigated, particularly in the context of broad-leaved evergreens, is cellular mechanisms of photoprotection during cold winters. Cold temperatures during winter can inhibit the enzymatic reactions of photosynthesis while not affecting the light absorption ability by overwintering evergreens. This can potentially result in photon flux in excess of that required for photosynthetic evolution of $\mathrm{O}_{2}$ [photosystem II (PSII) reaction centers] or assimilation of $\mathrm{CO}_{2}$. This excess energy, if not dissipated as heat or fluorescence, may cause inhibition of PSII reaction centers and/or photooxidative damage (Öquist and Huner, 2003). Evergreen species have evolved several mechanisms of photoprotection at suboptimal temperatures, and researchers have begun to address some of these only during the last decade (Adams et al., 2004; Demming-Adams and Adams, 2006; Niyogi, 1999; Verhoeven et al., 2005).

\section{DEACCLIMATION, MIDWINTER- HARDINESS, AND ACCLIMATION CAPACITIES: ARE THEY LINKED?}

As for the contribution of various components of overall winter-hardiness in woody perennials (as introduced earlier), it may be reasonable to assume that overwintering plants with high midwinter-hardiness would also exhibit a high degree of DA resistance and that a large maximal acclimation capacity and high DA resistance both represent evolutionary responses to low minimum temperatures, and the mechanisms responsible for these two processes might even be linked. To explore this notion, we initiated a study using deciduous azalea (Rhododendron L.) to examine the effect of genotypic or ecotypic biogeography on midwinter-hardiness and dehardening kinetics.

Nine azalea genotypes (species and varieties) were used in this study that represented eight seed provenances and multiple USDA cold hardiness zones (and midwinter-hardiness levels) making them good choices for comparative physiology. Natural habitats of these azaleas could be classified into three types: the southeastern lowlands, the Appalachian highlands, and the northeastern coastal region (Table 1) (Kalberer et al., 2007a). Buds from naturally (field) cold-acclimated plants were used (December to February) to evaluate midwinter freeze tolerance and deacclimation kinetics after exposure to a laboratory-controlled dehardening regime that included various durations (days) of deacclimation (DOD; Kalberer et al., 2007a, 2007b). To investigate whether there was an association between spring temperature fluctuations and dehardening kinetics, the variation in temperature to which each genotype was exposed historically in its seed provenance was calculated (Kalberer et al., 2007a); temperature range of a provenance was calculated for each month by taking the difference between the monthly maximum and minimum 30-year temperature averages (National Oceanic and Atmospheric Administration, 2002).

Results on DA kinetics revealed two categories of azalea genotypes: slow deacclimators (high DA resistance) and fast deacclimators (low DA resistance) (Fig. 1). Data further indicated that no unequivocal relationship between proclivity to deharden (or lack thereof) and either the minimum temperature of habitats or the midwinter-hardiness could be established. For example, Rhododendron prunifolium (Small) Millais showed both low midwinterhardiness and high DA resistance, whereas $R$. canadense (L.) Torr. had high midwinterhardiness (the highest among all genotypes investigated) but low DA resistance; $R$. canadense (native to the north Atlantic states and freeze-hardy to $-28.0^{\circ} \mathrm{C}$ in December) deacclimated faster than the more sensitive Georgian species $R$. prunifolium (freeze-hardy to $-24.6^{\circ} \mathrm{C}$ ) (Kalberer et al., 2007a). The recorded USDA hardiness zones for $R$. canadense are $3 \mathrm{~b}$ to 7 and the minimum average temperature for this provenance is $-10.9^{\circ} \mathrm{C}$, whereas that for the provenances of $R$. prunifolium is warmer than $-3{ }^{\circ} \mathrm{C}$.

Hence, whereas the degree of midwinterhardiness reflected the latitude and minimum temperatures of habitats, azaleas originating in cold climates and with high midwinterhardiness did not always exhibit high DA resistance, which is perhaps related to other climatic and developmental factors. Others have also made similar observations; among blueberry cultivars (Rowland et al., 2005), potato species (Vega et al., 2000) and filbert varities (Corylus L. spp.) (Hummer et al., 1986), high deacclimation resistance was not always associated with large acclimation capacities or high midwinter-hardiness. Similarly, 'Concord' grape (Vitis labrusca L.) had higher midwinter-hardiness than 'Cabernet Sauvignon' (Vitis vinifera L.), whereas the former deacclimated more rapidly (Wolf and Cook, 1992). Our recent work with Hydrangea species also indicates that a relatively hardier species, H. paniculata Sieb., is a relatively faster deacclimator than the lesshardy H. macrophylla (Thunb.) Ser. (Pagter et al., 2008, 2011). Furthermore, studies with cultivated potato indicated that the ability to acclimate rapidly is not always associated with a high CA capacity or high DA resistance; Solanum commersonii Dun. attained higher levels of hardiness $\left(-9.3{ }^{\circ} \mathrm{C}\right)$ than five other potato species but acclimated more slowly than some species and deacclimated faster than others (Vega et al., 2000). Observations outlined previously suggest that high DA resistance, high midwinter-hardiness, and the rate of CA represent distinctly different attributes and are perhaps inherited independently. Therefore, they should be evaluated separately when selecting and breeding for improved winter-hardiness.

\section{SELECTION FOR DEACCLIMATION- RESISTANCE IN PLANTS: WHAT MIGHT BE THE IMPETUS?}

The question arises as to which environmental or biological factors likely promote high DA resistance in plants. Conceivably, DA resistance is not determined by a single parameter but is possibly a function of the degree of temperature fluctuations (frequency and magnitude), particularly during the late winter and early spring to which plants are exposed in their native habitats rather than the low temperatures per se. Conceivably, plants growing under relatively stable conditions would experience little evolutionary pressure to develop DA resistance to transient increases in temperature. In our azalea study, we noted that, on the whole, genotypes originating in the Appalachian mountains had relatively high DA resistance. We believe that the more variable temperatures of the Appalachians, in comparison with the coastal plains, may promote the evolution of higher DA resistance. On the other hand, $R$. canadense, the hardiest species investigated and that mostly inhabits lowland, coastal regions of the northeastern United States and the maritime provinces of Canada had low DA resistance; dehardening would be less of a threat under cool and stable temperatures during winter and early spring and thus there would be little selective pressure for DA resistance. It may also be argued that the genotypes with greater midwinter-hardiness may experience less selective pressure for strong DA resistance than do less-hardy ones, because the former can safely lose a relatively large amount of acclimated hardiness before becoming vulnerable to cold injury.

Alternatively, high DA resistance could be prevalent in plants with delayed spring 


\begin{tabular}{|c|c|c|c|}
\hline Rhododendron genotype (common name) & Hardiness zones ${ }^{z}$ & Seed provenance ${ }^{y}$ & $\begin{array}{c}\text { Provenance minimum } \\
\text { temp. }\left({ }^{\circ} \mathrm{C}\right)^{\mathrm{x}}\end{array}$ \\
\hline canadense (rhodora) & $3 \mathrm{~b}$ to 7 & Long Pond in Poconos Mountains, PA & -10.9 \\
\hline prinophyllum (roseshell) & 4 to 8 & Spruce Knob, WV & -8.6 \\
\hline viscosum var. montanum (upland swamp) & ${ }^{\mathrm{w}}$ & Pisgah Swamp in Pisgah National Forest, NC & -5.0 \\
\hline arborescens (sweet) & $5 a$ to $8 b$ & Wayah Bald near Franklin, NC & -4.4 \\
\hline calendulaceum (flame) & $5 a$ to $8 b$ & Little Canada near Wolf Creek Reservoir, NC & -3.9 \\
\hline canescens (piedmont) & $6 \mathrm{~b}$ to 9 & Moody Springs, SC & -2.9 \\
\hline atlanticum (coastal) & $6 \mathrm{~b}$ to $8 \mathrm{~b}$ & Western border of Delaware & -2.8 \\
\hline prunifolium (plumleaf) & $6 \mathrm{~b}$ to $9 \mathrm{a}$ & Providence Canyon Park, GA & +0.6 \\
\hline viscosum var. serrulatum (hammock-sweet) & $7 \mathrm{a}$ to $9 \mathrm{a}$ & Provenance unknown & - \\
\hline
\end{tabular}

${ }^{2}$ USDA hardiness zones represent species distributions assigned by Galle (1974).

${ }^{y}$ Seed provenance information was provided by Natural Landscapes Nursery (West Grove, PA).

${ }^{x}$ Minimum temperatures represent 30 -year averages of the lowest monthly temperatures recorded during January of each year. Measurements are taken from the weather station closest to the provenance (National Oceanic and Atmospheric Administration, 2002), and the station is always located in the same state as the provenance. "No distribution of $R$. viscosum var. montanum is available in the scientific literature, but $R$. viscosum is distributed from 4a to 9a (Galle, 1974).

Source: Kalberer et al., 2007a.

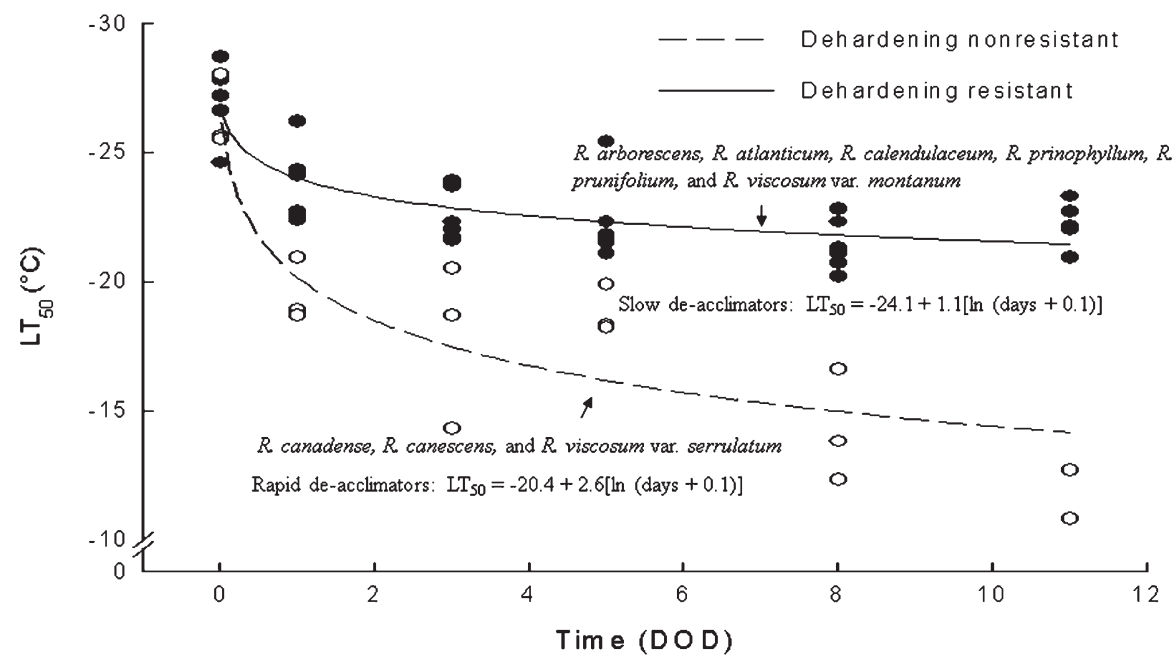

Fig. 1. Logarithmic-linear models of frost hardiness $\left(\mathrm{LT}_{50}\right)$ as a function of days of dehardening (DOD) for nine azalea genotypes. Rhododendron canadense, Rhododendron canescens, and Rhododendron viscosum var. serrulatum had dehardening kinetics representative of low dehardening resistance. The dehardening kinetics of Rhododendron arborescens, Rhododendron atlanticum, Rhododendron calendulaceum, Rhododendron prinophyllum, Rhododendron prunifolium, and Rhododendron viscosum var. montanum represented high dehardening-resistance (Source: Kalberer et al., 2007a).

development or deeper endo-/ecodormancy, because resumption of growth can lead directly or indirectly to irreversible deacclimation (Leinonen et al., 1997). Ample evidence exists to show that growth and development are not conducive to the retention of hardiness and that tissue hardiness is often negatively correlated with development (Mahfoozi et al., 2001a; Rapacz, 2002a, 2002b). Consistent with this notion, flower development of $R$. prunifolium, one of the slow deacclimator (DA-resistant) species used in our study, is slower than other native deciduous azaleas with anthesis in late summer, and a slow transition to active growth in these buds could explain the long-term maintenance of hardiness. The mechanism by which ontogenetic development modulates hardiness has been the subject of some speculation but relatively little research. Growth and development could have a negative effect on hardiness by altering the subcellular structure. For example, the increased cellular water and reduced cytosol to vacuole ratios that accompany cell expansion can render plants more susceptible to mechanical damage from extracellular ice and even promote intracellular freezing, which is invariably lethal (Levitt, 1980; Stitt and Hurry, 2002; Strand et al., 1999). Alternatively, active growth might interfere with deacclimation resistance by competing for energy resources (Levitt, 1980; Rapacz, 2002a, 2002b). Growth initiation involves developmental reprogramming requiring de novo gene expression that may have a deleterious influence on the maintenance of hardiness (Mahfoozi et al., 2001a, 2001b; Rapacz, 2002a, 2002b).

\section{REACCLIMATION CAPACITY: A SAFETY NET?}

RA is defined as a phenomenon whereby a deacclimated plant/tissue regains some or most of the lost hardiness if and when it is exposed to low temperatures (Kalberer et al., 2006). Therefore, the premature dehardening and low DA resistance, although a liability, may not necessarily always be deleterious to winter survival, especially if sufficient RA can quickly occur and somewhat mitigates the consequences of rapid dehardening. Even more desirable for a plant would be to have sufficient and efficient RA capacity even after a relatively long dehardening duration or substantial DA. Of course, for RA capacity to play a beneficial role in winter-hardiness, it is critical that the return of cold after premature DA is not too severe (in both the extent and suddenness) so as to allow sufficient reacclimation, which may not always happen in nature.

In our azalea study, the capacity to reharden to various extents was observed in diverse species from three regions after various amounts of dehardening: the southeastern lowlands $[R$. visocosum (L.) Torr. var. serrulatum (Small) Millais], the Appalachians [R. arborescens (Pursh) Torr., $R$. viscosum var. montanum Rehd.], and the northeastern coastlands (R. canadense) (Kalberer et al., 2007a, 2007b). Our results also indicated that only $24 \mathrm{~h}$ of low-temperature exposure $\left(12 \mathrm{~h}\right.$ at $2{ }^{\circ} \mathrm{C}$ followed by $12 \mathrm{~h}$ at $-2{ }^{\circ} \mathrm{C}$ ) was sufficient to reharden azalea buds post-DA and that RA occurred even after substantial dehardening in several genotypes (Kalberrer et al., 2007a, 2007b). Given that seasonal CA is a relatively gradual process, it is remarkable that dehardened buds of $R$. canadense and of the two latitudinal ecotypes, $R$. viscosum var. montanum and $R$. viscosum var. serrulatum, could regain up to $\approx 5,11$, and $9{ }^{\circ} \mathrm{C}$ of freeze tolerance, respectively, after only $1 \mathrm{~d}$ of exposure to a reacclimation regime (Kalberer et al., 2007a). Our data also indicated that the RA capacities in these azalea genotypes did not have a significant association with DA resistance. For example, two of the fast-deacclimator genotypes, $R$. canadense and $R$. viscosum var. serrulatum, exhibited highly divergent RA capacities; the former regained $\approx 5^{\circ} \mathrm{C}$ in response to a $24 \mathrm{~h}$ RA regime after $1 \mathrm{DOD}$, whereas the latter recovered only $0.6{ }^{\circ} \mathrm{C}$ with an identical treatment. No conclusions could be drawn about associations, if any, between the natural habitat and RA capacities in this study, and greater sample size will need to be examined to explore such relationships. Nevertheless, these results highlight that genetic variation, both inter- and intraspecific, for RA capacity exists in woody perennials and should be exploited in the breeding programs for improving winter-hardiness. 
Research shows that although reacclimation ability may be present in many overwintering plants, the RA capacity becomes more limited as the degree or duration of warm temperature exposure increases and DA advances. Apple bark tissues could reacclimate only to the hardiness level exhibited on the day previous to the final day of DA (Howell and Weiser, 1970). Gusta and Weiser (1972) exposed Korean boxwood to alternating temperature cycles $\left(25{ }^{\circ} \mathrm{C}\right.$ followed by $-10{ }^{\circ} \mathrm{C}$ ) and found that although DA was fully reversible after one such cycle, RA capacity declined with subsequent cycles. Whether such loss of RA capacity is the result of a lack of energy-producing substrates (required for acclimation), or irreversible developmental changes after deacclimation, or some other factor, or the combination of these factors, has not been determined.

\section{DEHYDRIN METABOLISM AND DEACCLIMATION/REACCLIMATION CYCLING}

Dehardening reverses physiological adaptations acquired during exposure to cold that endow plants with enhanced frost-hardiness. Numerous studies have reported an accumulation of dehydrins, hydrophilic members of the late embryogenesis abundant class of proteins, in bark, leaves, buds, and other tissues during CA of woody perennials (Marian et al., 2003). Dehydrin protein and transcript abundance declined to levels found in non-hardened plants during the dehardening of floral buds of blueberries (Vaccinium L.) (Arora et al., 1997) and bark tissues of peach [Prunus persica (L.) Batsch] (Artlip et al., 1997). Levels of a $60 \mathrm{kDa}$ dehydrin decreased on resumption of growth in needles of Scots pine (Pinus sylvestris L.) (Kontunen-Soppela et al., 2000). The rationale for the functional significance of such accumulation is that dehydrins, as a result of their hydrophilicity and putative chaperone properties, likely protect cellular membranes, enzymes, and macromolecules from freeze desiccation (Danyluk et al., 1998; Koag et al., 2003; Rinne et al., 1999). We observed that, in general, dehydrin levels fell and rose in response to changing ambient temperatures and were associated with loss and gain in bud freeze tolerance during dehardening and rehardening, respectively (Fig. 2) (Kalberer et al., 2007a). These observations are consistent with the putative role of dehydrins in freeze tolerance and provide support for potential use of dehydrin metabolism as a biochemical marker in dehardening and rehardening studies.

\section{DEACCLIMATION RESISTANCE, REACCLIMATION CAPACITY, AND WINTER PROGRESSION}

Another important question that needs to be examined is: how does winter progression, i.e., early versus late winter, influence DA resistance and RA capacity. To address this, we refer again to the azalea studies, with selected genotypes, in December (early win- ter) and in February (deep winter). In the Dec. 2004 study, rehardening in several azalea genotypes was observed even after only 1 DOD. However, in the Feb. 2006 study, rehardening did not occur until after 10 to 15 DOD. For example, in Dec. 2004, the buds of $R$. viscosum var. montanum rehardened by $\approx 4{ }^{\circ} \mathrm{C}$ even after 1 DOD (i.e., after dehardening by $\approx 3{ }^{\circ} \mathrm{C}$ ), whereas they rehardened by $\approx 2$ to $3{ }^{\circ} \mathrm{C}$ only after 10 to $15 \mathrm{DOD}$ by which time they had lost $\approx 14$ to $16{ }^{\circ} \mathrm{C}$ in freeze tolerance. Similarly, $R$. canadense buds were able to reharden in December by $\approx 5{ }^{\circ} \mathrm{C}$ after losing $\approx 9{ }^{\circ} \mathrm{C}$ in freeze tolerance after 1 DOD compared with $1.4{ }^{\circ} \mathrm{C}$ of rehardening in the February study after $5 \mathrm{DOD}$ and losing $18{ }^{\circ} \mathrm{C}$ in freeze tolerance (Kalberer et al., 2007a, $2007 b$ ). The ability of buds to reharden only when exposed to a relatively long dehardening duration suggests that, during the late winter, buds reharden only after a "threshold" level of dehardening is reached. Perhaps levels of certain proteins or metabolites may need to decrease, or water content may need to increase, beyond a certain point during dehardening before rehardening can be induced. Alternatively, it may take a longer period of time to reprogram the tissues to cold-acclimate once they have begun to resume growth and development. Therefore, could the difference in RA capacities of buds between the Dec. 2004 and Feb. 2006 studies be related to differences in the depth of endodormancy? In other words, could it be that the greater depth of dormancy in December (as a result ofless fulfillment of chilling requirements), compared with in February (i.e., shallower dormancy resulting from greater accumulation of chill-units), favorably influences rehardening even after low levels of dehardening?

\section{DORMANCY AND DEACCLIMATION RESISTANCE OR REACCLIMATION CAPACITY}

Dormancy can be defined as a temporary suspension of visible growth of any plant structure containing a meristem (Lang et al., 1987). When the dormancy-inducing, environmental or endogenous signals (e.g., low temperature, short photoperiod, hormones, etc.) are specifically perceived within the affected meristem and the dormancy-regulating factors instantiated by those signals also originate from inside of the affected structure, it is called endodormancy. This is different from ecodormancy that includes growth suspension resulting from nonconducive environmental factors (e.g., hot or cold temperatures, dehydration, nutrient deficiencies, etc.) (Lang et al., 1987).

Dormancy often inhibits or prevents the deacclimation that accompanies resumption of growth. Tart cherry (Prunus cerasus L.) floral buds have been shown to resist deacclimation during endodormancy such that buds closer to emerging from endodormancy are more susceptible to deacclimation (Callan, 1990). Exposure of red-osier dogwood (Cornus sericea L.) to $24 / 18^{\circ} \mathrm{C}$ (day/night) did not induce significant deacclimation of endodormant stems, but once dormancy was broken, the deacclimation was rapid (Litzow and Pellett, 1980). Deaccli- mation kinetics of mountain birch ecotypes were associated with chilling requirements predicted from altitude, latitude, and distance from the coast (Taulavuori et al., 2004). Wintercollected floral buds from $R$. kiusianum Mak. fall-bloom clones deacclimated after 4 weeks at $17{ }^{\circ} \mathrm{C}$ but buds of spring-bloom (dormant) clones did not (Iwaya-Inoue and Kaku, 1986). We too observed that DA resistance declined in some azalea genotypes ( $R$. canadense, $R$. viscosum var. montanum) with the progression of winter and, therefore, the decline of endodormancy (more fulfillment of chilling requirements). However, the same was not observed in some other genotypes (R. arborescens, $R$. canescens) (Kalberer et al., 2007b).

The intensity of dormancy may also modulate the RA capacity of overwintering plants. As mentioned, the RA capacity of certain azalea genotypes declined with greater fulfillment of chilling requirements (winter progression). Similarly, a study with Viburnum L. has shown that dormant plants exhibited greater RA capacity of 6 to $11^{\circ} \mathrm{C}$ in midwinter compared with non-dormant plants that could only reacclimate by $7{ }^{\circ} \mathrm{C}$ or less (Irving and Lanphear, 1967).

\section{PHOTOPROTECTION STRATEGIES IN OVERWINTERING EVERGREENS: ROLE OF ELIPS}

In the ecophysiological context of winterhardiness, especially for evergreens, it is important to ask: how do these plants manage incident light during cold winters? As alluded to earlier, the conundrum that temperate-zone evergreens (including broad-leaved species) face is that the green leaves continue to harvest light under conditions in which absorbed solar energy cannot be processed as a result of inhibition of photosynthetic apparatus by subfreezing temperatures. This may lead to overexcitation of photosynthetic apparatus, even at ambient fluence levels, which, in turn, may cause photooxidative damage, and plants may be injured or killed well above the freeze-killing temperature determined by the low temperature alone. Therefore, evergreens must possess mechanisms to manage and/or tolerate light stress during cold winters, a topic that has been a subject of some reviews lately (Adams et al., 2004; DemmingAdams and Adams 2006; Öquist and Huner 2003).

As understory evergreens in the deciduous forests, leaves of most broad-leaved rhododendrons are commonly exposed to a combination of freezing temperatures and high light in their natural habitat during winter. Our expressed sequence tag (EST) study with NA and CA leaf tissues of $R$. catawbiense Michx. indicated a downregulation of several photosynthesis-related genes (e.g., RuBisCO small subunit precursor, RuBisCO activase, plastidic fructose bisphosphate aldolase, chloroplast precursor of plastocyanin) in overwintering leaves suggesting that it could potentially lead in light energy harvested by the leaves to be in excess of what can be processed by photosystems. This research also revealed that cDNAs 

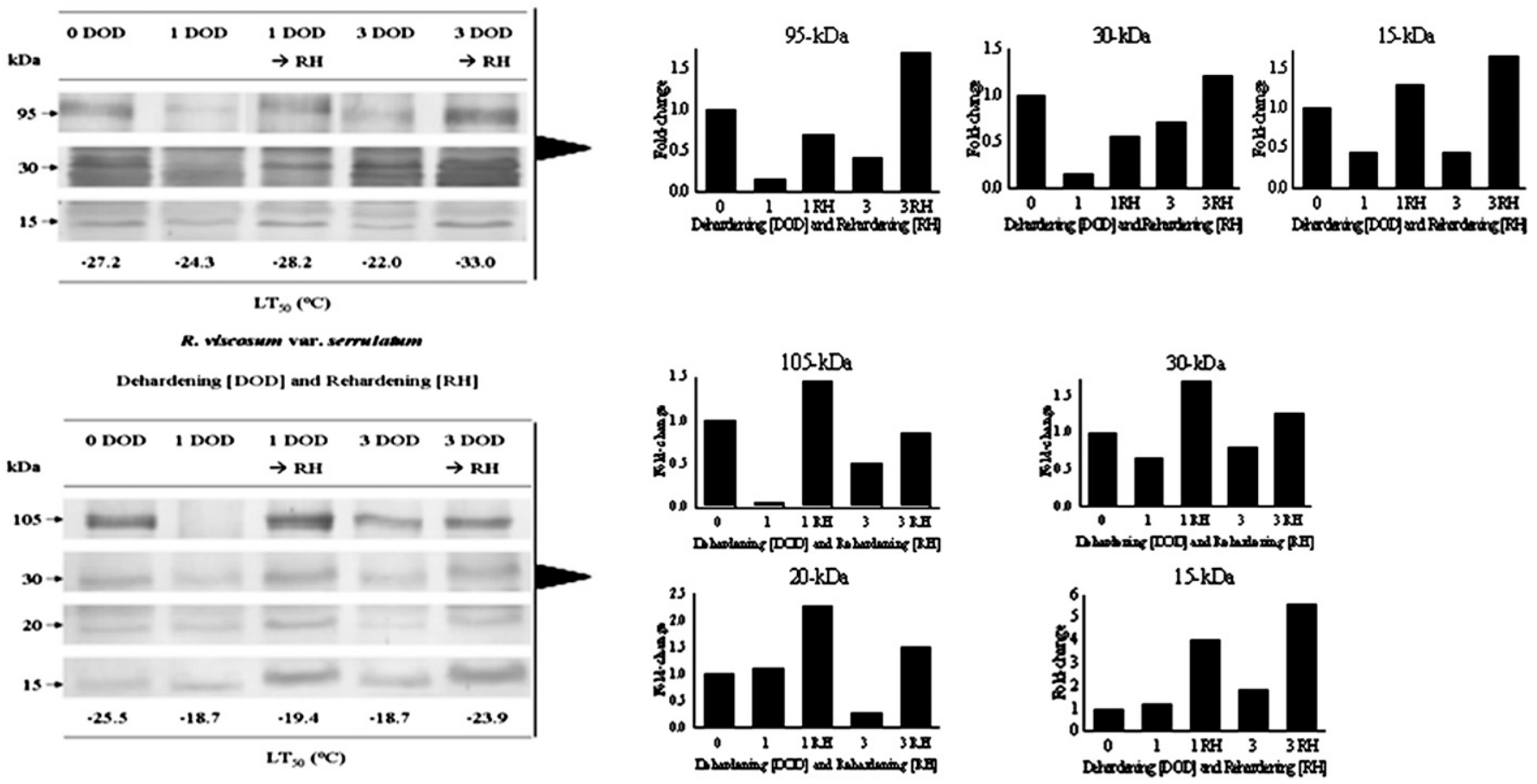

Fig. 2. Effect of dehardening and rehardening on the abundance of dehydrins for Rhododendron viscosum var. montanum, and Rhododendron viscosum var. serrulatum. (A) Antidehydrin immunoblot profiles of floral bud proteins. Antibody specificity was tested by using an antibody-antigen conjugate as a negative control. The days of dehardening (DOD), use of rehardening $(\mathrm{RH}), \mathrm{LT}_{50}$ for each genotype and treatment, and the estimated molecular weight (kDa) of dehydrins are indicated for each band of interest. All lanes containing a given dehydrin were loaded on an equal protein basis; (B) estimates of the relative levels of dehydrins for each genotype during dehardening and rehardening given by densitometric analyses of the immunoblots (Source: Kalberer et al., 2007a).

encoding Elip homologs were the most abundant class in an EST library generated from winter-collected (CA) leaf tissues and no Elips were detected in the EST data set for NA (summer-collected) leaves (Wei et al., 2005); these Elips ESTs were later catalogued into seven distinct RcElips (for R. catawbiense Early light induced proteins) (Peng et al., 2008). Elips are nuclear-encoded, light stress-induced proteins located in thylakoid membranes and belong to the chlorophyll $a / b$-binding protein family with a wide distribution among plant species (Adamska, 2001). It is proposed that Elips may transiently bind the released chlorophylls under high light stress and prevent the formation of free radicals and/or function in energy dissipation (Adamska, 2001; Montané and Kloppstech, 2000). Elip accumulation, therefore, may constitute an adaptive response to winter conditions (cold and high light) in evergreens and play a key role in the protection of photosynthetic apparatus from excess light.

Our more recent work revealed a significant upregulation of the transcripts of seven RcElips from August to December in two Rhododendron species, a less hardy $R$. ponticum L. (midwinter leaf-freeze tolerance of $\approx-20{ }^{\circ} \mathrm{C}$ ) and superhardy $R$. catawbience (leaf-freeze tolerance of $\approx-50{ }^{\circ} \mathrm{C}$ ) (Wang et al., 2009). Further investigation of the seasonal profiles at the protein level should be beneficial to uncover the possible role of RcElips in these two species. Moreover, a strong positive correlation between the degree of CA ability and corresponding increment in Elips accumulation in the two species divergent in their freezing tolerance (Fig. 3) suggests that an enhanced ability of leaves to protect chloroplast from excess light may be one of the key components of a multifactorial cold acclimation process in evergreen rhododendrons. Others have also reported an accumulation of Elip proteins in winter-collected leaves of several evergreens - subalpine firs and lodgepole pines (Zarter et al., 2006a) and bearberry (Zarter et al., 2006b) but little to no accumulation in the summer-collected samples. Collectively, these studies point toward a potential role of Elips in the photoprotection scheme by overwintering evergreens and further research is warranted to fully understand their functional significance. However, other possible, heretofore unknown, functional roles of Elip upregulation in conferring freezing tolerance cannot be ruled out.

Interestingly, the rate of seasonal increase in Elip abundance (per unit change in leaf freeze tolerance calculated as the $\mathrm{LT}_{50}$ ) for $R$. catawbiense was twice that for $R$. ponticum, suggesting that $R$. catawbiense perhaps needs more efficient upregulation of photoprotection systems than $R$. ponticum. This notion is, curiously, bolstered by the fact that $R$. catawbiense exhibits thermonasty, whereas $R$. ponticum does not. Thermonasty refers to temperatureinduced leaf movements, a phenomenon in which leaves droop and curl at freezing temperatures in winter (Nilsen, 1987). One of the proposed adaptive benefits (among others) of thermonastic leaf movement is the avoidance of high light stress in the winter by reducing leaf exposure to light (Bao and Nilsen, 1988) and thereby facilitating relatively faster recovery of PSII efficiency in spring (Russell et al., 2009) . Lack of thermonastic behavior in $R$. ponticum, therefore, suggests that this species may perhaps be more tolerant of light stress in winter than $R$. catawbiense. Our results on the seasonal patterns of PSII efficiencies in the two species indicate that $R$. catawbiense leaves underwent significantly greater photoinhibition during fall and winter compared with $R$. ponticum, indicating relatively higher sensitivity to light stress of the former (Wang et al., 2009).

\section{NATURAL (FIELD) VERSUS ARTIFICIAL (CONTROLLED ENVIRONMENT) COLD ACCLIMATION: APPRECIATING THE DIFFERENCES IN CONTEXT OF RESEARCH OUTCOMES}

Another issue to address, as we try to further our understanding of the development of cold-hardiness in plants, and in woody perennials in particular, is the choice of experimental protocols for achieving CA. In the literature, we often find that researchers acclimate plants under artificial regimes such 
(A)

$R$. catawbiense

Leaf $\mathrm{LT}_{50}$ in Jan $=-35^{\circ} \mathrm{C}$

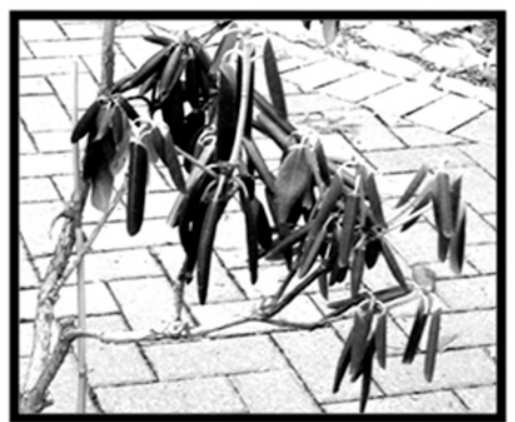

Thermonasty
R. ponticum

Leaf $\mathrm{LT}_{50}$ in $\mathrm{Jan}=-20^{\circ} \mathrm{C}$

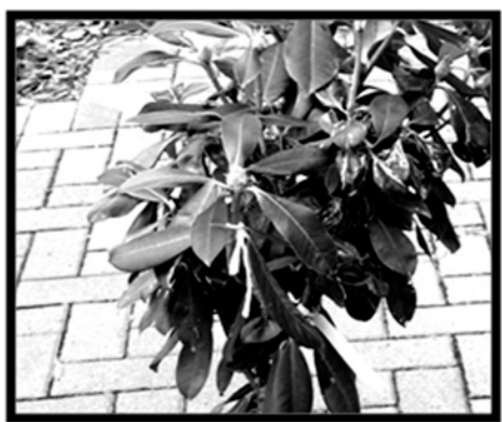

No Thermonasty

(B)

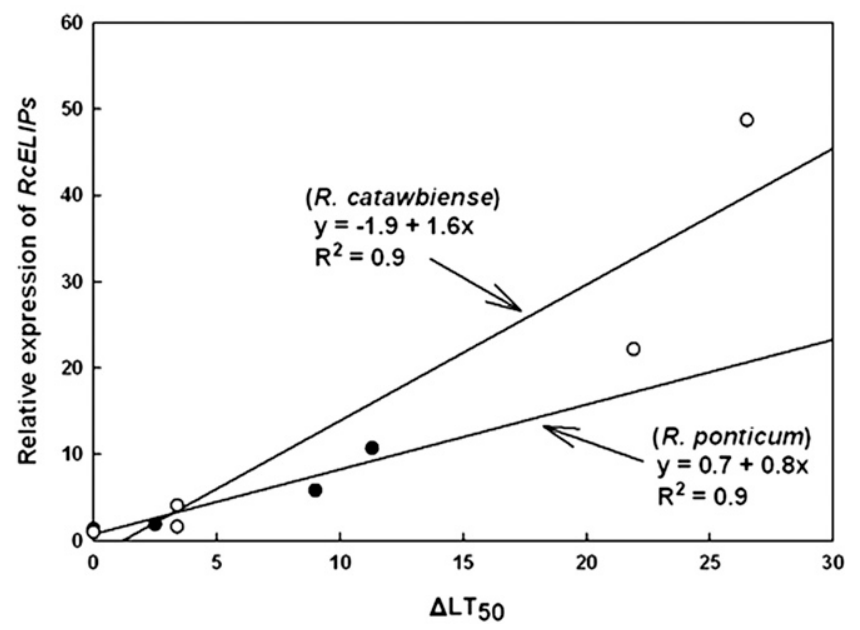

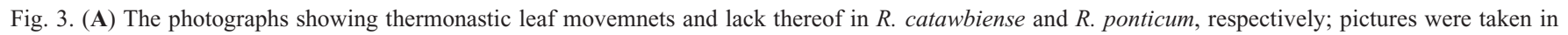
January when the leaf-freezing tolerances (expressed as $\mathrm{LT}_{50}$ ) for field-acclimated potted plants were -35 and $-20{ }^{\circ} \mathrm{C}$, respectively. $(\mathbf{B})$ Regression of relative expression of RcElips on changes in leaf freezing tolerance $\left(\Delta \mathrm{LT}_{50}\right)$, a measure of cold acclimation ability, for $R$. ponticum and $R$. catawbiense. The relative expression of RcElips for each species in each month was calculated relative to their expression in August (taken as 1) and is based on the average of seven RcElips. $\Delta \mathrm{LT}_{50}$ are the absolute values of $\mathrm{LT}_{50}$ difference between August and subsequent months until the December sampling (Source: Wang et al., 2009).

as placing potted plants in growth chambers, typically at a constant $4{ }^{\circ} \mathrm{C}$, with fairly low light levels, for 1 to several weeks. This protocol has the advantage of being fairly "controllable" and may be sufficient for herbaceous annuals, which primarily acclimate in response to above-freezing, low temperatures over a short duration and by only a few degrees. Woody perennials, on the other hand, generally achieve greater levels of cold-hardiness than do herbaceous annuals, being able to withstand lower freezing temperatures over a longer duration. In woody perennials, CA proceeds in stages and is triggered by several environmental cues - short photoperiod, low temperatures (both above and below freezing), available moisture, etc. In nature, these factors change gradually - decreasing daylengths, declining temperatures into the freezing and below-freezing ranges, and declining moisture. Also, in nature, there are generally warmer day and cooler night temperatures. The light intensity is typically higher than in cold room acclimation regimes, and the light quality is different and varies seasonally.

In our studies on a typical northern highbush blueberry cultivar, Bluecrop, we have found that flower buds of field plants (in Beltsville, MD) have an $\mathrm{LT}_{50}$ of $\approx-13{ }^{\circ} \mathrm{C}$ in October and reach a minimum flower bud $\mathrm{LT}_{50}$ (maximum level of cold-hardiness) of $\approx-27^{\circ} \mathrm{C}$ by mid-December, when plants have accumulated $\approx 600$ chilling-units (Fig. 4). Cold-hardiness levels tend to decline in February and March with the return of warmer temperatures. For the southern rabbiteye blueberry cultivar Tifblue, flower buds have an $\mathrm{LT}_{50}$ of $\approx-12{ }^{\circ} \mathrm{C}$ in October and an $\mathrm{LT}_{50}$ of $\approx-25{ }^{\circ} \mathrm{C}$ in mid-December (Fig. 4). Coldhardiness levels begin declining in January. In contrast, under cold room conditions of constant $4{ }^{\circ} \mathrm{C}$ and short photoperiod (10 h light/ $14 \mathrm{~h}$ dark), 'Bluecrop' and 'Tifblue' plants reach a maximum level of cold-hardiness of $\approx-24^{\circ} \mathrm{C}$ and $-17{ }^{\circ} \mathrm{C}$, respectively $\left(3\right.$ to $8{ }^{\circ} \mathrm{C}$ less hardy than field-acclimated plants $)$ by $\approx 500 \mathrm{~h}(\approx 3$ weeks). Cold-hardiness levels remain constant as long as plants are kept in the cold room (Arora et al., 1997).

In recent years, we have taken a genomic approach to identify genes associated with CA in blueberry by generating ESTs from cDNA libraries prepared from NA and CA flower buds of the northern highbush cultivar
Bluecrop and using these ESTs to construct a microarray. The original microarray (for blueberry) included $\approx 2400$ cDNAs, 1200 from each of the NA and CA libraries. This microarray was first used to compare changes in gene expression of 'Bluecrop' plants acclimated under two different regimes - naturally under field conditions and in pots in a cold room environment with constant temperature $\left(4{ }^{\circ} \mathrm{C}\right)$ and a constant photoperiod (10 h light/14 h dark). Changes in levels of gene transcripts were examined in flower buds at multiple times during cold acclimation under field $(\approx 0,70,400,800$, and 1200 chill-units) and cold room conditions ( 0 , 500, and 1000 chill-units) (Dhanaraj et al., 2007; Rowland et al., 2008a).

First, results indicated that many of the same genes were induced under both environments. These included many genes previously identified as part of the cold-response pathway in Arabidopsis (Fowler and Thomashow, 2002; Hannah et al., 2005; Seki et al., 2001) such as genes encoding galactinol synthase, beta amylase, LEAs, dehydrins, and ELIPs and also genes not previously observed to be cold-induced in Arabidopsis such as genes encoding protein kinase PINOID involved in 


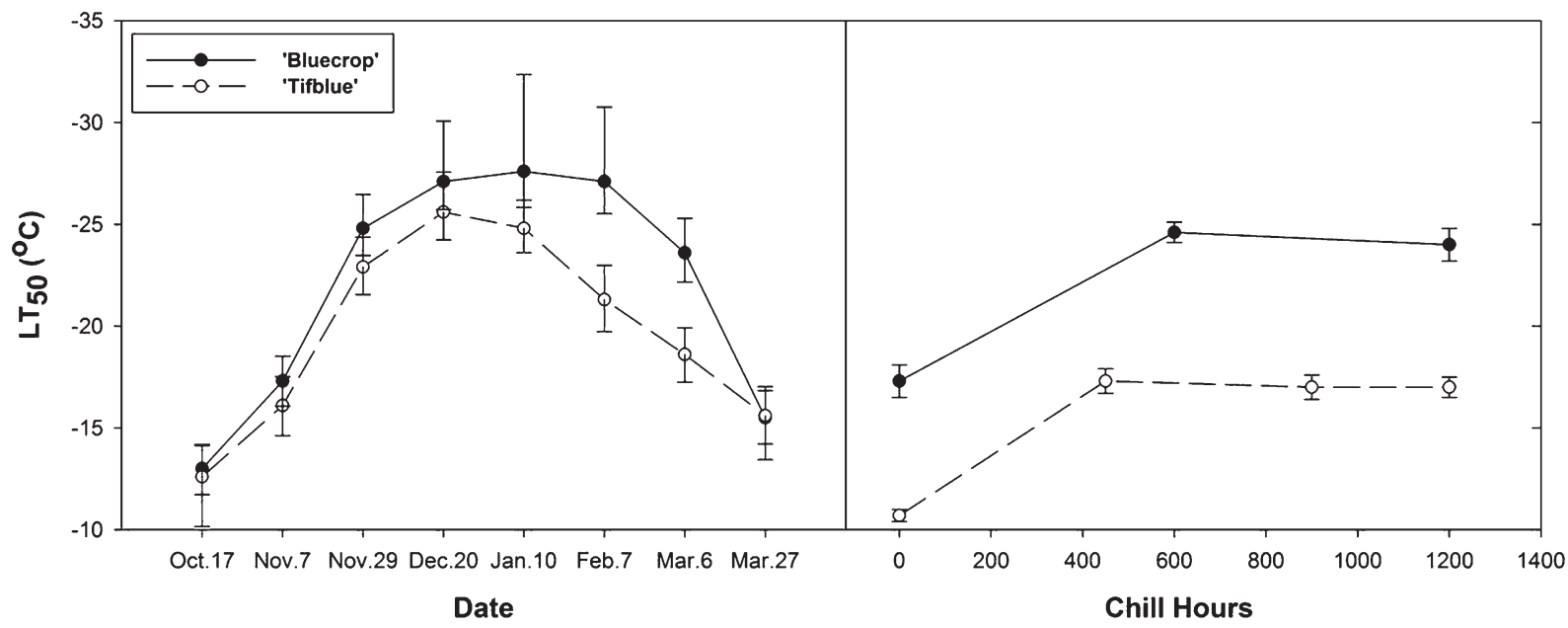

Fig. 4. Typical cold-hardiness levels (temperature causing $50 \%$ injury or the $\mathrm{LT}_{50}$ from a freeze-thaw test) of 'Bluecrop' and 'Tifblue' flower buds under field and cold room conditions. Under field conditions, cold-hardiness levels generally reach a maximum approximately mid-December ( $\approx 600$ chill-units) and then begin to decline as temperatures warm and buds begin to open (Rowland et al., 2008b). Under cold room conditions, cold-hardiness levels reach a maximum $\approx 500$ chill-units ( 3 weeks of exposure to $4^{\circ} \mathrm{C}$ ) and remain constant as long as plants are kept in the cold room (Arora et al., 1997). 'Bluecrop' and 'Tifblue' flower buds are generally 2 to $3{ }^{\circ} \mathrm{C}$ hardier and 7 to $8{ }^{\circ} \mathrm{C}$ hardier, respectively, under field conditions than under cold room conditions.

auxin-mediated signaling, pectate lyase, and S-adenosylmethionine decarboxylase proenzyme. However, marked differences in gene expression were also observed under the two $\mathrm{CA}$ regimes. In general, the number of coldinduced genes was higher and the number of cold-suppressed genes was lower in the cold room than in the field (Fig. 5). Indeed, the number of genes induced under cold room conditions was approximately twice that induced under field conditions, although 'Bluecrop' field plants are $3{ }^{\circ} \mathrm{C}$ more cold-hardy than cold room plants, indicating that all the induced genes in the cold room environment likely do not contribute to increased hardiness. It is possible that some of the genes induced in the cold room may be associated with lowtemperature growth acclimation rather than the freezing tolerance per se. Many of the genes induced under cold room conditions that were not induced under field conditions could be divided into three major groups: 1) general stress tolerance genes; 2) genes encoding glycolytic and tricarboxylic acid cycle enzymes; and 3) genes encoding protein synthesis machinery. Some of the genes induced under both environments, particularly genes associated with light stress, were induced to higher levels under field conditions than a cold room. Furthermore, many of the genes suppressed under field conditions, that were not suppressed under cold room conditions, reached maximum suppression by the 400 chill-unit sampling, at which point average outside temperatures had dropped below freezing to $-2.1{ }^{\circ} \mathrm{C}$ from an average of $6.3{ }^{\circ} \mathrm{C}$ the week before. Thus, it is possible that these genes may have been suppressed in response to freezing temperatures, explaining their lack of suppression in the cold room environment. Many of these suppressed genes were in fact the same general stress genes that were induced in the cold room setting such as genes encoding heat shock proteins, phospholipid hydroperoxide

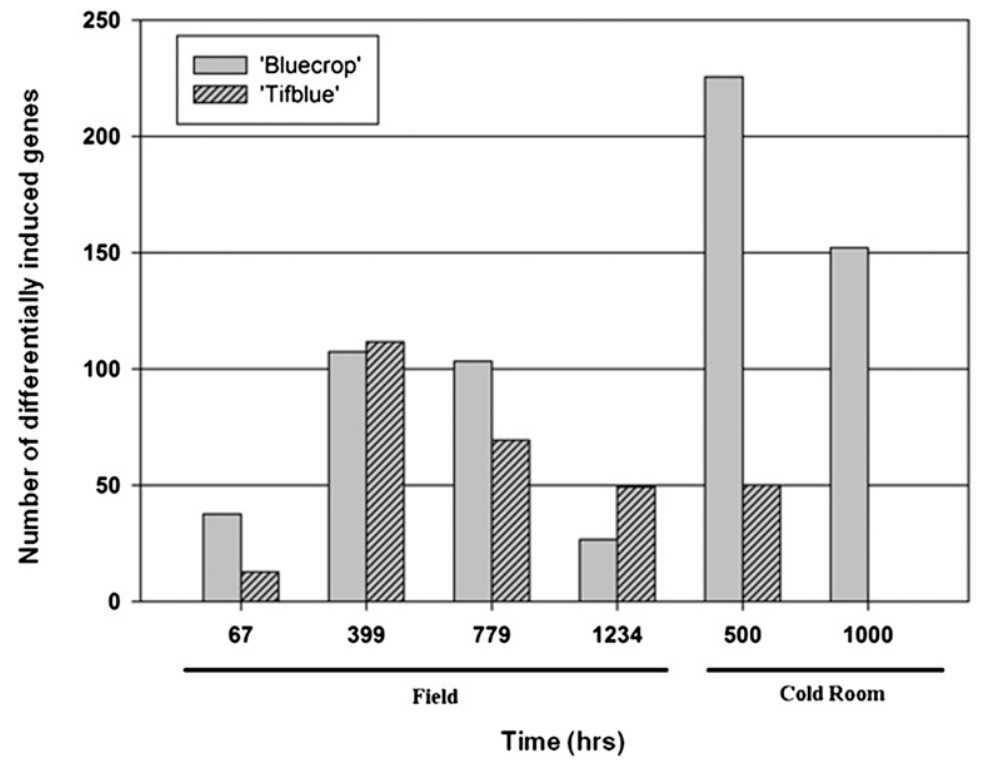

Fig. 5. From microarray experiments, the number of upregulated genes detected in 'Bluecrop' (Dhanaraj et al., 2007) and 'Tifblue' (unpublished) at each time point (hours exposure from 0 to $7^{\circ} \mathrm{C}$ ) of two cold acclimation regimes (natural/field and artificial/cold room).

glutathione peroxidase, and low temperatureinduced $78 \mathrm{kD}$ protein. From this, it is interesting to speculate that, in 'Bluecrop', cold room conditions may result in induction of a larger general stress response, whereas freezing conditions in the field result in more selective expression.

Just to complicate matters even more, we have also now compared gene expression of the southern rabbiteye cultivar Tifblue under field and cold room acclimation regimes (unpublished data). Surprisingly, in contrast to 'Bluecrop', more genes were induced in 'Tifblue' under field conditions than under cold room conditions (Fig. 5). Some of the genes induced in 'Tifblue' in the field, that were not induced in the cold room, were genes that were highly induced in both environments in 'Bluecrop' such as genes encoding galactinol synthase, a cell wall glycine-rich protein, and water stress ER-5. Thus, not only do plants respond differently under these different CA regimes, but their responses are genotype-, or perhaps ecotype-, dependent. It appears that the southern cultivar Tifblue may require lower temperatures, or a different light regime than was provided in the cold room, to induce its complete suite of cold-responsive genes.

Using wheat as a model, Herman et al. (2006) found that subzero acclimation or SZA (an additional 3 to $5^{\circ} \mathrm{C}$ increase in freezing tolerance upon exposure to $\approx-3^{\circ} \mathrm{C}$ ) is accompanied by 
changes in physiology, cellular structure, the transcriptome, and the proteome distinct from those observed during a "typical" CA regime (freezing tolerance acquired at above freezing temperatures). In terms of the transcriptome, they found that many unknown and stressrelated genes were upregulated, whereas many photosynthesis and plastid-related genes were downregulated during SZA as compared with "typical" CA. From a proteome standpoint, they noted a loss of many proteins as opposed to the appearance of new proteins in SZA samples. Thus, like in blueberry, subfreezing temperatures appeared to result in much suppression of gene expression.

In summary, these studies highlight the need for researchers to begin using more realistic CA protocols in controlled environments that more accurately approximate natural/field conditions. For woody perennials, in particular, a subzero temperature regime should be included to achieve full CA potential and the full complement of CA-related gene expression.

\section{CONCLUDING REMARKS}

Predicted global climate change may have dramatic effects on the extent and location of winter injury because the frequency of extreme and unseasonable weather events are likely to increase in the future. Such scenarios could disturb the timing of seasonal CA and $\mathrm{DA}$ in overwintering woody perennials. Therefore, the plants that are able to resist premature, rapid DA, as well as quickly RA when cold returns, might have a better chance of surviving cold winters. Discussion outlined here suggests that winter survivability of perennials is a complex, multicomponent response in which early initiation of acclimation, high midwinterhardiness, high DA resistance, and efficient RA capacity all represent distinctly different components of this complex. For a successful breeding program focused on improving winterhardiness, it is important to determine which aspect of winter-hardiness, if not all (acclimation timing and speed, midwinter-hardiness, DA resistance, RA capacity), might be the most limiting for a given species and a location and accordingly select appropriate parents to introduce these traits. Another layer of complexity that should be carefully considered, in this context, is that endodormant status (shallow versus deep) of the reproductive/vegetative apices can significantly impact these components of winter-hardiness.

Winter survival, especially by woody evergreens, is not only coping with the cold (and associated desiccation), but also requires tolerance of other environmental factors that may become stressful even when present at ambient levels; a case in point: light, which can result in photo-oxidative damage at cold temperatures when the enzymatic facet of photosynthetic process is sluggish. Overwintering evergreens have evolved with various photoprotection strategies to manage such stress, including xanthophyll cycle, antioxidant systems, certain adaptive anatomical as well morphological features, etc. Accumulation of Elips in overwintering evergreens during winter represents a relatively novel strategy to cope with light stress. In-depth investigations on the mechanistic physiology and genetic control of this strategy deserve attention in the future.

Finally, recent genomic research comparing plants under different $\mathrm{CA}$ regimes (natural/field versus artificial/cold room and low/above freezing versus subzero freezing temperatures) indicates that there are major differences in gene expression under the different environments, and the differences may be genotype-dependent. To draw meaningful conclusions about the biology of CA and ultimately improve freeze resistance under real-life conditions, more efforts should be made by the cold-hardiness research community to design experiments to sort out the major reasons for these differences such as presence of subfreezing temperatures and higher light levels under field conditions, as implicated in the experiments described here. Once this is determined, more realistic CA protocols in controlled environments can be developed and implemented.

\section{Literature Cited}

Arctic Climate Impact Assessment. 2005. Cambridge University Press. 1042.

Adams W.W., III, C.R. Zarter, V. Ebbert, and B. Demmig-Adams. 2004. Photoprotective strategies of overwintering evergreens. Bioscience 54:41-49.

Adamska, I. 2001. The elip family of stress proteins in the thylakoid membranes of pro- and eukaryote, p. 487-505. In: Aro, E.M. and B. Andersson (eds.). Advances in photosynthesis and respiration-regulation of photosynthesis. Kluwer Academic Publishers, Dordrecht, The Netherlands.

Arora, R., L.J. Rowland, L.S. Lehman, C.-C. Lim, G.R. Panta, and N. Vorsa. 2000. Genetic analysis of freezing tolerance in blueberry. Theor. Appl. Genet. 100:690-696.

Arora, R., L.J. Rowland, and G.R. Panta. 1997. Chill responsive dehydrins in blueberry: Are they associated with cold hardiness or dormancy transitions? Physiol. Plant. 101:8-16.

Artlip, T.S., A.M. Callahan, C.L. Bassett, and M.E. Wisniewski. 1997. Seasonal expression fo dehydrin gene in sibling deciduous and evergreen peach [Prunus persica (L.) Batsch.]. Plant Mol. Biol. 33:61-70.

Bao, Y. and E.T. Nilsen. 1988. The ecophysiological significance of leaf movements in Rhododendron maximum L. Ecology 69:1578-1587.

Bertrand, A. and Y. Castonguay. 2003. Plant adaptations to overwintering stresses and implications of climate change. Can. J. Bot. 81:1145-1152.

Browse, J. and B.M. Lange. 2004. Counting the cost of a cold-blooded life. Proc. Natl. Acad. Sci. USA 101:14996-14997.

Callan, N.W. 1990. Dormancy effects on supercooling in deacclimated 'meteor' tart cherry flower buds. J. Amer. Soc. Hort. Sci. 115:982-986.

Danyluk, J., A. Perron, M. Houde, A. Limin, B. Fowler, N. Benhamou, and F. Sarhan. 1998. Accumulation of an acidic dehydrin in the vicinity of the plasma membrane during cold acclimation of wheat. Plant Cell 10:623-628.

Demming-Adams, B. and W.W. Adams, III. 2006 Photoprotection in an ecological context: The remarkable complexity of thermal dissipation. New Phytol. 172:11-21.

Dhanaraj, A.L., N.W. Alkharouf, H.S. Beard, I.B. Chouikha, B.F. Matthews, H. Wei, R. Arora, and L.J. Rowland. 2007. Major differences observed in transcript profiles of blueberry during cold acclimation under field and cold room conditions. Planta 225:735-751.

Fowler, S. and M.F. Thomashow. 2002. Arabidopsis transcriptome profiling indicates that multiple regulatory pathways are activated during cold acclimation in addition to the CBF cold response pathway. Plant Cell 14:1675-1690.

Galle, F. 1974. Southern living: Azaleas. Oxmoor House, Birmingham, AL

Gu, L., P.J. Hanson, W. MacPost, D.P. Kaiser, B. Yang, R. Nemani, S.G. Pallardy, and T. Meyers. 2008. The 2007 eastern US spring freeze: Increased cold damage in a warming world? Bioscience 58:253-262.

Gusta, L.V. and C.J. Weiser. 1972. Nucleic acid and protein changes in relation to cold acclimation and freezing injury of Korean boxwood leaves. Plant Physiol. 49:91-96.

Gusta, L.V., M.E. Wisniewski, and R.G. Trischuk. 2009. Patterns of freezing in plants: The influence of species, environment and experiential procedures, p. 213-225. In: Gusta, L.V., M.E. Wisneiwski, and R.G. Trischuk (eds.). Plant cold hardiness: From the laboratory to the field. CAB International.

Guy, C.L. 1990. Cold acclimation and freezing tolerance: Role of protein metabolism. Annu. Rev. Plant Physiol. 41:187-233.

Guy, C.L. 2003. Freezing tolerance of plants: Current understanding and selected emerging concepts. Can. J. Bot. 81:1216-1223.

Hannah, L., G.F. Midgley, G. Hughes, and B. Bomhard. 2005. The view from the cape:extinction risk, protected areas and climate change. Bioscience $55: 231-242$

Herman, E.M., K. Rotter, R. Premakumar, G. Elwinger, H. Bae, L. Ehler-King, S. Chen, and D.P. Livingston, III. 2006. Additional freeze hardiness in wheat acquired by exposure to $-3^{\circ} \mathrm{C}$ is associated with extensive physiological, morphological, and molecular changes. J. Expt. Bot. 57:3601-3618.

Howell, G.S. and C.J. Weiser. 1970. Fluctuations in the cold resistance of apple twigs during spring dehardening. J. Amer. Soc. Hort. Sci. 95:190-192.

Hummer, K., H.B. Lagerstedt, and S.K. Kim. 1986. Filbert acclimation, maximum cold hardiness, and deacclimation. J. Amer. Soc. Hort. Sci. 111: 474-482.

Intergovernmental Panel on Climate Change. 2007, Climate change 2007: The physical science basis, summary for policymakers. $<$ http://www. ipcc.ch>.

Irving, R.M. and F.O. Lanphear. 1967. Dehardening and the dormant condition in Acer and Viburnum. Proc. Am. Soc. Hort. Sci. 91:699-705.

Iwaya-Inoue, M. and S. Kaku. 1986. Cold hardiness and acclimation intensity in flower buds for fall bloom and spring bloom clones in Rhododendron kiusianum, a dwarf evergreen azalea. Plant Cell Physiol. 27:515-521.

Kalberer, S.R., N. Leyva-Estrada, S.L. Krebs, and R. Arora. 2007a. Frost dehardening and rehardening of floral buds of deciduous azalea are influenced by genotypic biogeography. Environ. Exp. Bot. 59:264-275.

Kalberer, S.R., R. Arora, N. Leyva-Estrada, and S.L. Krebs. 2007b. Cold hardiness of floral buds of deciduous azaleas: Dehardening, rehardening, and endodormancy in later winter. J. Amer. Soc. Hort. Sci. 132:73-79.

Kalberer, S.R., M. Wisniewski, and R. Arora. 2006. Deacclimation and reacclimation of cold-hardy plants: Current understanding and emerging concepts. Plant Sci. 171:3-16.

Kaplan, F., D.-Y. Sung, and C.L. Guy. 2006. Roles of $\beta$-amylase and starch breakdown during 
temperature stress. Physiol. Plant. 126:120128.

Koag, M.-C., R.D. Fenton, S. Wilkens, and T.J. Close. 2003. The binding of maize DHN1 to lipid vesicles. Gain of structure and specificity. Plant Physiol. 131:309-316.

Kontunen-Soppela, S., K. Taulavuori, E. Taulavuori, P. Lähdesmäki, and K. Laine. 2000. Soluble proteins and dehydrins in nitrogen-fertilized scots pine seedlings during deacclimation and the onset of growth. Physiol. Plant. 109:404 409.

Lang, G.A., J.D. Early, G.C. Martin, and R.L. Darnell. 1987. Endo-, para- and ecodormancy: Physiological terminology and classification for dormancy research. HortScience 22:371-377.

Leinonen, I., T. Repo, and H. Hänninen. 1997. Changing environmental effects on frost hardiness of scots pine during dehardening. Ann. Bot. (Lond.) 79:133-138.

Levitt, J. 1980. Responses of plants to environmental stresses. Academic Press, New York, NY.

Litzow, M. and H. Pellett. 1980. Relationship of rest to dehardening in red-osier dogwood. HortScience 15:92-93.

Mahfoozi, S., A.E. Limin, and D.B. Fowler. 2001a. Developmental regulation of low temperature tolerance in winter wheat. Ann. Bot. (Lond.) 87:751-757.

Mahfoozi, S., A.E. Limin, and D.B. Fowler. 2001 b. Influence of vernalization and photoperiod responses on cold hardiness in winter cereals. Crop Sci. 41:1006-1011.

Marian, C.O., S.L. Krebs, and R. Arora. 2003. Dehydrin variability among rhododendron species: A $25-\mathrm{kDa}$ dehydrin is conserved and associated with cold acclimation across diverse species. New Phytol. 161:773-780.

Moffatt, B., V. Ewart, and A. Eastman. 2006. Cold comfort: Plant antifreeze proteins. Physiol. Plant. 126:5-16.

Montané, M.H. and K. Kloppstech. 2000. The family of light harvesting-related proteins (LHCs, ELIPs, HLIPs): Was the harvesting of light their primary function? Gene 258:1-8.

National Oceanic and Atmospheric Administration. 2002. Climatography of the United States no. 81: Monthly station normal of temperature, precipitation, and heating and cooling degree days: 19712000. National Climate Data Center/National Oceanic and Atmospheric Administration.

Nilsen, E.T. 1987. Influence of water relations and temperature on leaf movements of Rhododendron species. Plant Physiol. 83:607-612.

Niyogi, K.K. 1999. Photoprotection revisited: Genetic and molecular approaches. Annu. Rev. Plant Physiol. Plant Mol. Biol. 50:333-359.

Öquist, G. and N.P.A. Huner. 2003. Photosynthesis of overwintering evergreen plants. Annu. Rev. Plant Biol. 54:329-355.

Pagter, M., J.-F. Hausman, and R. Arora. 2011. Deacclimation kinetics and carbohydrate changes in stem tissues of Hydrangea in response to an experimental warm spell. Plant Sci. 180: 140-148.

Pagter, M., C.R. Jensen, K.K. Petersen, F. Liu, and R. Arora. 2008. Changes in carbohydrates, ABA and bark proteins during seasonal cold acclimation and deacclimation in Hydrangea species differing in cold hardiness. Physiol. Plant. 134:473-485.
Pan, A., P.M. Hayes, F. Chen, T.H.H. Chen, T. Blake, S. Wright, I. Karsai, and Z. Bedo. 1994. Genetic analysis of the components of winterhardiness in barley. Theor. Appl. Genet. 89: 900-910.

Pearce, R.S. and M.P. Fuller. 2001. Freezing of barley studied by infrared video thermography. Plant Physiol. 125:227-240.

Peng, Y., W. Lin, H. Wei, S.K. Krebs, and R. Arora. 2008. Phylogenetic analysis and seasonal cold acclimation-associated expression of early lightinduced protein genes of Rhododendron catawbiense. Physiol. Plant. 132:44-52.

Rapacz, M. 2002a. Cold-deacclimation of oilseed rape (Brassica napus var. oleifera) in response to fluctuating temperatures and photoperiod. Ann. Bot. (Lond.) 89:543-549.

Rapacz, M. 2002b. Regulation of frost resistance during cold de-acclimation and re-acclimation in oilseed rape. A possible role of PSII redox state. Physiol. Plant. 115:236-243.

Renaut, J., J.-F. Hausman, and M.E. Wisniewski. 2006. Proteomics and low temperature studies: Bridging the gap between gene expression and metabolism. Physiol. Plant. 126:97-109.

Rinne, P.L.H., P.L.M. Kaikuranta, L.H.W. van der Plas, and C. van der Schoot. 1999. Dehydrins in cold-acclimated apices of birch (Betula pubescens Ehrh.): Production, localization and potential role in rescuing enzyme function during dehydration. Planta 209:377-388.

Rowland, L.J., A.L. Dhanaraj, D. Naik, N. Alkharouf, B. Matthews, and R. Arora. 2008a. Study of cold tolerance in blueberry using EST libraries, cDNA microarrays, and subtractive hybridization. HortScience 43:1975-1981.

Rowland, L.J., E.L. Ogden, M.K. Ehlenfeldt, and R. Arora. 2008b. Cold tolerance of blueberry genotypes throughout the dormant period from acclimation to deacclimation. HortScience 43: 1970-1974.

Rowland, L.J., E.L. Ogden, M.K. Ehlenfeldt, and B. Vinyard. 2005. Cold hardiness, deacclimation kinetics, and bud development among 12 diverse blueberry genotypes under field conditions. J. Amer. Soc. Hort. Sci. 130:508-514.

Russell, R.B., T.T. Lei, and E.T. Nilsen. 2009. Freezing induced leaf movements and their potential implications to early spring carbon gain: Rhododendron maximum as exemplar. Funct. Ecol. 23:463-471.

Seki, M., M. Narusaka, H. Abe, M. Kasuga, K. Yamaguchi-Shinozaki, P. Carninci, Y. Hayashizaki, and K. Shinozaki. 2001. Monitoring the expression pattern of 1300 Arabidopsis genes under drought and cold stresses by using a full-length cDNA microarray. Plant Cell 13:61-72.

Smallwood, M. and D.J. Bowles. 2002. Plants in a cold climate. Philos. Trans. R. Soc. Lond. B Biol. Sci. 357:831-847.

Stitt, M. and V. Hurry. 2002. A plant for all seasons: Alterations in photosynthetic carbon metabolism during cold acclimation in Arabidopsis. Curr. Opin. Plant Biol. 5:199-206.

Stone, J.M., J.P. Palta, J.B. Bamberg, L.S. Weiss, and J.F. Harbage. 1993. Inheritance of freezing resistance in tuberbearing Solanum species: Evidence for independent genetic control of nonacclimated freezing tolerance and cold acclimation ability. Proc. Natl. Acad. Sci. USA 90:7869-7873.

Strand, A., V. Hurry, S. Henkes, N. Huner, P. Gustafsson, P. Gardeström, and M. Stitt. 1999. Acclimation of Arabidopsis leaves developing at low temperatures. Increasing cytoplasmic volume accompanies increased activities of enzymes in Calvin cycle and in the sucrose-biosynthesis pathway. Plant Physiol. 119:1387-1397.

Sutka, J. 1981. Genetic studies of frost resistance in wheat. Theor. Appl. Genet. 59:145-152.

Taulavuori, K.M.J., E.B. Taulavuori, O. Skre, J. Nilsen, B. Igeland, and K.N. Laine. 2004. Dehardening of mountain birch (Betula pubescens spp. czerepanovii) ecotypes at elevated winter temperatures. New Phytol. 162:427-436.

Van Buskirk, H.A. and M.F. Thomashow. 2006. Arabidopsis transcription factors regulating cold acclimation. Physiol. Plant. 126:72-80.

Vega, S.E., J.P. Palta, and J.B. Bamberg. 2000. Variability in the rate of cold acclimation and deacclimation among tuber-bearing Solanum (potato) species. J. Amer. Soc. Hort. Sci. 125: 205-211.

Verhoeven, A.S., A. Swanberg, M. Thao, and J. Whiteman. 2005. Seasonal changes in leaf antioxidant systems and xanthophylls cycle characteristics in Taxus $\times$ media growing in sun and shade environments. Physiol. Plant. 123: 428-434.

Wang, X., Y. Peng, J.W. Singer, A. Fessehaie, S.L. Krebs, and R. Arora. 2009. Seasonal changes in photosynthesis, antioxidant systems and ELIP expression in a thermonastic and non-thermonastic Rhododendron species: A comparison of photoprotective strategies in overwintering plants. Plant Sci. 177:607-617.

Warren, G.J. 1998. Cold stress: Manipulating freezing tolerance in plants. Curr. Biol. 8:R514 R516.

Wei, H., A.L. Dhanaraj, L.J. Rowland, Y. Fu, S.K. Krebs, and R. Arora. 2005. Comparative analysis of expressed sequence tags (ESTs) from cold-acclimated and non0acclimated leaves of Rhododendron catawbiense Michx. Planta 221: 406-416.

Wisniewski, M., C. Bassett, and L.V. Gusta. 2003. An overview of cold hardiness in woody plants: Seeding the forest through the trees. HortScience 38:952-958.

Wolf, T.K. and M.K. Cook. 1992. Seasonal deacclimation patterns of three grape cultivars at constant, warm temperature. Amer. J. Enol. Viticult. 43:171-179.

Xin, Z. and J. Browse. 2000. Cold comfort farm: The acclimation of plants to freezing temperatures. Plant Cell Environ. 23:893-902.

Zarter, C.R., W.W. Adams, III, V. Ebbert, D.J. Cuthbertson, I. Adamska, and B. Demmig-Adams. 2006a. Winter down-regulation of intrinsic photosynthetic capacity coupled with up-regulation of Elip-like proteins and persistent energy dissipation in a subalpine forest. New Phytol. 172: 272-282.

Zarter, C.R., W.W. Adams, III, V. Ebbert, I. Adamskia, S. Jansson, and B. Demmig-Adams. 2006b. Winter acclimation of PsbS and related proteins in the evergreen Arctostaphylos uvaursi as influenced by altitude and light environment. Plant Cell Environ. 29:869-878. 